Research Note

CONVICT CRIMINOLOGY AT THE CROSSROADS ${ }^{1}$

\author{
by \\ Greg Newbold, PhD \\ Professor \\ School of Social and Political Sciences \\ University of Canterbury \\ Pte Bag 4800 \\ Christchurch 8140 \\ New Zealand \\ greg.newbold@canterbury.ac.nz \\ Jeffrey Ian Ross, PhD \\ Associate Professor \\ School of Criminal Justice \\ College of Public Affairs \\ University of Baltimore \\ 1420 North Charles Street \\ Baltimore, $\mathrm{MD}$ \\ 21201 \\ jross@ubalt.edu
}

Revised: Thursday August 18, 2011

Word count: 2634

\footnotetext{
${ }^{1}$ Special thanks to Barbara Zaitzow for comments.
} 
Research Note

\title{
CONVICT CRIMINOLOGY AT THE CROSSROADS
}

\begin{abstract}
This research note critiques both the past and current status of Convict Criminology. It notes the subtle changes that have occurred within this approach to the study of corrections and the criminal justice system, and some of the controversies that have emerged. It discusses these issues and makes recommendations about Convict Criminology's future direction.
\end{abstract}


An endemic feature of scholarly thinking is its evolving nature. As the German philosopher Georg Hegel (1807/1971) noted, dialectical discourse within any discipline is inimical to its vibrancy and progress. Others have offered similar observations. Thomas Kuhn (1970), for example, argued that scientific debates are not necessarily progressive in fact they tend to be somewhat faddish. Whatever the case, ideas seldom survive long without amendment, review or challenge. In an ideal world, the best ideas are accepted and incorporated, while bad ones are consigned to the scrapheap of history.

In the field of criminal justice, we have seen numerous debates over correctional philosophy and practice. As is well known, the prison system itself was originally based on contesting philosophies and practices concerning punishment (see, e.g., Cohen and Scull (eds), 1985; Foucault 1977, Morris and Rothman (eds), 1995) and further refined in Pennsylvania and New York. Over the last two centuries, these debates have produced the correctional system we have today.

If we look at the approach to criminology embraced under the general heading of 'Convict Criminology' we can see a similar process occurring. Developed during the early 1990s, Convict Criminology was originally conceived as a panacea for perceived shortcomings in scholarship within the fields of criminology/criminal justice in general, and corrections in particular. The scholars closely associated with the discipline, nearly all former convicts, argued that what was missing from contemporary writing and research was input from those who had been subject to incarceration. Their contention was that policy makers and practitioners need to listen to, and take into account, the research-based opinions of men and women who have experienced what Sykes (1970) called the 'pains of imprisonment.'

On conference panels and in other public forums, however, some of the founders went further than this, inferring that people acquire uniquely-inspired thinking through being in prison, and that the longer they are inside and the more brutal the conditions, the deeper grows their insight. Some even ventured to imply that unless a person had been incarcerated in a jail or prison, his/her writing on the subject was suspect or reduced in value.

Not all contributors to the Convict Criminology perspective have concurred with this view. In fact, what has become clear with the passage of time is that, notwithstanding our underlying agreement that the voices of those who have 'lived' the prison experience need to be harkened, there is great variety within the group and lively debate about a range of issues. Convict Criminology is no monolithic beast and many of its members, albeit connected by their prison histories or subject specialization, express a mixture of attitudes and views. The group is highly diverse and it has no single perspective.

The purpose of this paper is to identify some of the divergent trends and epistemological debates that have emerged within the school of Convict Criminology in recent years. We consider the implications of these developments, and comment upon the future of the 'school' (as it is sometimes referred to) as we see it. 


\section{The Challenges}

From the time of its formation, Convict Criminology has encountered a number of verbal and written challenges, particularly from well-regarded scholars who contested the opinions of the school's most radical members (Lilly, 2009) Some have criticized the Convict Criminologists for lacking in objectivity, for over-generalizing about the work of non-convict scholars, for parading their ex-convict status as if it gives them a premium on insight, for making grandiose claims about their own achievements, and for blaming career failures on anti-convict prejudice (see, e.g., Bosworth, 2004; Maghan, 2004). Privately, the worst critics have condemned Convict Criminologists as callow dilettantes who try to disguise their indifferent abilities, with proprietary claims to insight.

It is easy to see how these views were formed. Some of the early Convict Criminology conference panel discussions tended to become a litany of war stories, and to belittle non-convict writers. At times, participants laid claim to higher understanding based on prison experience. Indeed, in private conversation, a few Convict Criminologists expressed even stronger views than those voiced publicly. Many are embittered by experiences of perceived injustice within the prison system and by what they see as prejudicial treatment from the academic community. This has been another frequent topic of panel discussion which is also found in the early drafts of some papers. We know that some potential participants have been repelled by it. Consequently, a number of members have since argued that the school as a whole is undermined if its representatives become preoccupied with personal grievances. Scholarly writing and research, they say, should seek to remain impartial. In order to be taken seriously, these critics insist that convict scholars should be aware of, and avoid, the tendency to proselytize or emote.

A related matter of contention is the issue of balance. Although Convict Criminology's founders recognized that the triple purposes of the school are those of conducting research, working for prison reform, and mentoring the incarcerated, this needs to be handled in a measured way. In order to produce positive policy change, for example, recommendations need to be based on robust research that is published in quality-assured venues. If the group is to mentor effectively and provide leading role models for the incarcerated, it must have credibility in the eyes of the academic and general public. Both come from the same source. If Convict Criminologists compromise standards and choose to publish medium quality, sometimes repetitive research rather than a smaller amount of carefully conducted and innovative work, their effectiveness in informing policy change, and their status in the eyes of observers, will be limited. Thus, Convict Criminology's ability to influence change and to mentor others is ultimately dependent on the production of high-quality work. This work must be disseminated in respected scholarly forums in order to demonstrate how the perspective can contribute to the criminological enterprise. To date, representation of the group in top-tier academic journals is relatively low. 


\section{The Membership}

As originally conceived, the term, 'Convict Criminology' referred to "convicts or exconvicts, on their way to completing or already in possession of a PhD" (Ross and Richards, 2003, p.6). It also included PhD-educated prison reform advocates, who, because of their research interests, believed that the convict voice is underutilized. In many respects, this is the 'old school' definition. Over the past five years, an emphasis on mentoring and recruitment has led to the label 'Convict Criminologist' often being extended to almost anyone with an interest in corrections, irrespective of their formal credentials. As a result, the school has become infused with members who, although articulate and intelligent, lack the training required for advanced degrees such as the $\mathrm{PhD}$. Because of this, some of the writing and discourse is below the standard that would survive a rigorous peer-review. As founding members of the school, we see this as a dangerous development.

The erosion in discipline within Convict Criminology is evidenced in a profusion of unsupported statements and generalizations that have begun to appear in public venues and popular writing. Apologists may argue that prison sociology should be rhetorical as much as scientific, and that bringing change is as important as producing knowledge. If this is so, then it is a major corruption of the vision of the founding membership, which was firmly based on science. In our view, if Convict Criminology is to be taken seriously we must accept that its primary role is the production of information and fact-based understanding, not the manufacture of polemic. Well-founded knowledge may indeed lead to welcome change, but the current authors see themselves primarily as academics, not activists, who are thereby bound by the same scholarly rules as anybody else.

Thus, although a prison experience may provide a kind of Weberian verstehen, it is no substitute for careful, controlled research. If time spent behind bars was the only criterion for being an authority, then every hospital patient would be an expert on the health care system. One of the great weaknesses of this 'privileged knowledge' approach is that it is based on the false assumption that all prisoners experience incarceration the same way. Nothing could be further from the truth. Correctional institutions vary widely in terms of physical structure, security level, management style, and inmate composition. These differences affect their custodial populations in numerous ways. Moreover, even within a single institution, solitary white males are likely to have entirely different experiences to ethnic gang members, just as lifers have different experiences to shorttermers and women have different experiences to men.

So where does this leave the non-accredited prison memoir? A number of former prisoners have produced interesting personal accounts of their imprisonment (e.g., Abbott 1981; Boyle, 1977; McVicar, 1979; Newbold, 1982; Rideau and Wikberg, 1992, Runyon 1954; Zeno 1970), and these are useful as far as they go. They provide valuable source material for the very good academic prison studies which discuss the culture, structure and character of the inmate world (e.g.,Clemmer, 1958; Cohen and Taylor, 1972; Goffman, 1962, Irwin and Cressey, 1962; Jacobs, 1977; Morris and Morris, 1962; Ross

and Richards, 2002; Sykes, 1958; Winfree, Newbold and Tubb, 2002). But most of the 
material currently at hand is dated and contemporary research is scant. This is where the $\mathrm{PhD}$-trained Convict Criminologist is in his/her element. Today, there is a growing body of Convict Criminologists with PhDs capable of doing sound ethnographic work on prison society using not just personal experience, but also employing robust methods of empirical social science (see, eg, Lenza, 2011; McLellan et al, 1996; Ross and Richards (eds), 2003; Winfree, Newbold and Tubb, 2002). This is something that the group's late founding mentor John Irwin called for at virtually every conference where he served as a discussant and mentor. If Convict Criminology is to rise to its full potential, the production of high-quality research on prison life and its impacts, and on how various factors affect prisoners' sentence length and post-release careers, would appear of critical importance. We see this as an important direction for Convict Criminology to take in the future.

As we see it, Convict Criminology currently sits at a crossroads. One road is the road of activism. Activism requires large, energetic membership and the production of significant amounts of lobby material and propaganda. As we have seen with the "Three Strikes' legislation, activism can be extremely successful if it manages to excite the masses with sensational examples and emotive argument. However, research and logic often take a back seat in this process, and so may common sense and honesty. The other road is the academic. The academic road is tortuous and slow. It requires critical inquiry followed by informed and rational debate. Although its achievements are likely to be less spectacular than those of the successful activist, because its basis is scientific, its chances of enduring success, in our submission, are likely to be greater. If Convict Criminology is to make a significant, long-term contribution to policy and practice in criminal justice, therefore, we argue that it needs to resist the tendency to proselytize and instead to focus on producing information derived from research that is careful, disciplined and robust.

\section{Conclusion}

As Hegel, Kuhn and others have observed, intellectual thought progresses through rigorous critical scrutiny and debate. Since its birth, Convict Criminology has been subjected to such a process from without as well as from within (see Jones, Ross, Richards, and Murphy, 2009). As a result, we believe the group has tightened its disciplinary focus and established itself as a bona fide school within the field of social science. However, we have argued that the relatively low contribution of the group to high-ranking refereed journals, combined with its recent tendency to recruit writers who lack the type of training typically associated with advanced degrees, threatens this hardwon status. We believe that unless outputs bearing the Convict Criminology label are able to withstand incisive review and critique, the academic status of the group will be compromised. In our submission, sacrificing strict academic rigor for popular activism will spell the end of Convict Criminology as an accredited source of knowledge and as an agency of scientific inquiry. 


\section{References}

Abbott, J.H. (1991). In the Belly of the Beast. New York: Vintage Books.

Bosworth, M. (2004). "Book Review of Convict Criminology." British Journal of Criminology, vol. 44, no. 6, pp. 988-990.

Boyle, J. (1977). A Sense of Freedom. London: Macmillan.

Clemmer, D. (1958). The Prison Community. New York: Rinehart.

Cohen, S. and Scull, A. (eds) (1985). Social Control and the State. Oxford: Basil Blackwell.

Cohen, S. and Taylor, L. (1972). Psychological Survival: The Experience of Long-Term Imprisonment. Harmondsworth, Middlesex, UK: Penguin.

Foucault, M. (1977). Discipline and Punish: The Birth of the Prison. New York: Pantheon.

Goffman, E. (1961). Asylums: Studies on the Social Situation of Mental Patients and Other Inmates. Chicago: Aldine.

Hegel, G. (1807/1971). The Phenomenology of Mind. Tr. J.B. Baillie. London: Allen and Unwin.

Irwin, J. and Cressey, D. (1962). “Thieves, Convicts and Inmate Culture.” Social Problems, Vol. 2: pp. 142-155.

Jacobs, J. (1977). Stateville: The Penitentiary in Mass Society. Chicago: University of Chicago Press.

Jones, R., Ross, J.I., Richards, and Murphy, D.S. (2009). “The First Dime: A Decade of Convict Criminology,” The Prison Journal, Vol. 89, No. 2, pp. 151-171.

Kuhn, T. (1970). The Structure of Scientific Revolutions. Chicago: University of Chicago Press.

Lenza, M. (2011). “The Importance of Postmodern Autoethnography and Ethnography in Criminal Justice Research and Policy Development”. In I.O. Ekunwe and R.S. Jones (eds), Global Perspectives on Re-Entry, Tampere, Finland, University of Tampere Press. 
Lilly, R. J. 2009. Book Review: Carceral, K. C. (2006). Prison, Inc.: A Convict Exposes Life Inside a Private Prison. Edited by T. J. Bernard. New York: New York University Press. In Criminal Justice Review, Vol. 34, No. 3, pp. 460-462.

Maghan, J. (2004). "Ex-Con Professors". Book Review of Convict Criminology, www.amazon.com . Downloaded June 1, 2011.

McLellan, V; Saville-Smith, K, and Newbold, G. (1996). Escape Pressures: Inside Views of the Reasons for Prison Escapes. Wellington: Department of Corrections.

McVicar, J. (1979). McVicar, By Himself. London: Arrow.

Morris, T. and Morris, P. (1962). Pentonville: A Sociological Study of an English Prison. London: Routledge and Kegan Paul.

Morris, N. and Rothman, D.J. (eds) (1995). The Oxford History of the Prison. New York: Oxford University Press.

Newbold, G. (1982). The Big Huey. Auckland: Collins.

Rideau, W. and Wikberg, R. (1992). Life Sentences: Rage and Survival Behind the Bars. New York: Times Books.

Ross, J.I. and Richards, S. (2002). Behind Bars: Surviving Prison. Indianapolis, Ind: Alpha Books.

Ross, J.I. and Richards, S. (Eds.), (2003). Convict Criminology. Belmont, Ca: Thomson/Wadsworth.

Runyon, T. (1954). In for Life.London: Deutsch.

Sykes, G. (1970). “The Pains of Imprisonment”. In N. Johnston, L. Savitz and M.E. Wolfgang (Eds.), The Sociology of Punishment and Correction. NY: Wiley.

Sykes, G. (1958). The Society of Captives: A Study of a Maximum Security Prison. Princeton: Princeton University Press.

Winfree, T; Newbold, G. and Tubb, H. (2002). "Prisoner Perspectives on on Inmate Culture in New Mexico and New Zealand: A Descriptive Case Study." The Prison Journal, Vol. 82, No. (1): 213-233.

Zeno (1970). Life. London: Pan. 